\title{
Development of on Line-Based Evaluation on Material of Environmental Damage Prevention
}

\author{
Karma Iswasta Eka \\ Universitas Muhammadiyah Purwokerto, \\ karmaiswastaeka@ump.ac.id
}

\author{
Zada Talitha Ramdhani \\ UniversitasMuhammadiyah Purwokerto, \\ zadatalitha@gmail.com
}

\begin{abstract}
The main objective of this study was to develop an online-based evaluation instrument using Moodle material of environmental damage prevention for fourth graders in SD/MI (primary school). This study also aimed to determine the feasibility of onlinebased evaluation instrument using Moodle; to find out the effect of online-based evaluation instrument using Moodle on natural science subject learning achievement; to discover response of teachers and students to online-based evaluation instrument using Moodle on natural science subject. This research and development stage referred to the development model according to Thiagarajan 1974. The research data were collected through test and non-test techniques. The tests were given in the form of pre-test and while non-test was in the form of questionnaire. The effect of online-based evaluation instrument using Moodle on natural science subject learning achievement was able to be figured out by experiments. The experimental design used was true control group design involving control and experimental classes. The average expert validation result was 4.6 indicating that online-based evaluation instrument using Moodle was feasible to be utilized in the learning process. The results also showed that there was an effect of online-based evaluation instrument using Moodle on natural science subject learning achievement. Another result was excellent response of teachers and students as evidenced by the average teacher responses of 4.5 and 4.26 for student responses.
\end{abstract}

Keywords: evaluation,moodle,natural science

\section{INTRODUCTION}

Education supported by information technology can make students adapted to the development flow of information technology and communication. Those who are accustomed to using ITC devices are indirectly developing their skill in those fields and later can develop their quality. Article No. 48, 57, and 59 of the Government Regulation No. 17 of 2010 also stated that in organizing and managing national education system in education units or programs, the organizers should develop and implement information systems in education based on information and communication technology. Learning model and strategy as well as infrastructure and facilities in the technology based learning evaluation are expected to make students more interested in learning and more easily understand the learning.

[1]Arikunto explained that measurement and evaluation are foreign terms. Basically evaluation is the act to collect information about how something works by comparing one measurement, then taking a decision on that something with good or bad measurement (evaluating).

One of web applications which can be developed as e-learning or CBT is Moodle. [2]Darmawan stated that Moodle is a CMS (Content Management System) with web-based application which needs a web server as the media to run properly. Moodle can be used in both intranet and internet. Intranet can only be used for a narrow scope such as a school computer laboratory. It needs a web server which has been installed with Apache Software and Xampp. Students can access it anywhere and it needs domain and hosting with large capacity.

Schoology-based E-learning research has ever been done by [3]Aminoto and Pathoni in Jambi. The results show that Schoology-based E-learning affects the student's learning motivation in SMAN Jambi. Schoology enables teachers to deepen learning process with the students outside the class. [4]Eka explained that the fast development of Science and Technology including the learning process demanded the teachers to adjust themselves, so the old teaching style would be left behind because the students with technology awareness would be steps ahead from their teachers or even lecturers.

Online-based evaluation instrument with Moodle also has some advantages. The first advantage isan interactive relation between the evaluation instruments and the students. [5]Darmawan stated that interactivity can be enabled directly or indirectly and visually complete (multimedia) or not. The kinds of question items are more interactive and interesting such as simulation video, animation, and image. Those evaluation instruments can help the students to analyze question and concept on the material. In addition, Natural Science subject on material of environmental damage prevention needs visual and audio description which is based on reality.

The second advantage is feedback and affirmation. [6]Darmawanstated that feedback is the center of evaluation. Feedback directly affects the students in learning. The examples of feedback include: 1) feedback from teacher with assignments, 2) peer evaluation which is provided by students, 3) questions from teacher, and 4) direct feedback which is automatically provided by the 
computer. These evaluation instruments help teachers to get the feedback on learning process directly and efficiently, and the student's work does not need to be manually checked by teacher or the students themselves. Teachers will directly know the student's scores which will also help the teacher's work. Moreover, the recent government regulation prohibits teachers to use Student's Worksheet and demand teachers to make the questions. The use of evaluation instruments can also motivate the students with their new experience.

The third advantage is flexibility. [7]Surjono stated that the advantage of e-learning is its flexibility. The learning material can be accessed anytime and anywhere through e-learning, so it can create student's learning independence. Learning independence is a must in this era. Evaluation instruments and materials in Moodle can guide students to do e-learning and to be independent in which they can do their homework and assignment anywhere.There are question items and explanations on the material of environmental damage prevention, so students and teachers can use those evaluation instruments before the evaluation to recall the material they have learnt.

The development of Online-based Natural Science evaluation instruments using Learning Management System (LMS) Moodle on the material of environmental damage prevention for the fourth grade students of Primary School is expected to help students in analyzing questions and concept on the material, doing independent learning, attracting student's interest in learning, and helping teacher to evaluate.

\section{METHOD}

The development of these evaluation instruments used research and development.Research and development is a research method which is used to result certain product and test the effectiveness of that product. The development model used in this research referred to 4-D model development of [6]Thiagarajan, Semmel, and Semmel. The data collecting technique was done to find out the information related to the research using test and non-test technique. The test techniques were pre-test and post-test, while the non-test techniques were questionnaire of expert's validation, teacher's response, and student's response.

\section{RESULT}

Product validation is done by two experts. Questionnaires of instrument and material validation consist of 20 assessed items. The assessment is conducted once, and has been declared valid, but there are some suggestions and criticism from the validators

The results are in four sections. The first section is development of online-based evaluation instrument for Natural Science subject using Moodle on material of environmental damage prevention for fourth grade students in primary school. The second section is validation result of the development of online-based evaluation instrument. The third section is responses of teachers and students after the application of onlinebased evaluation instrument. The fourth section is the effect after applying the online-based evaluation instrument by using Moodle on material of environmental damage prevention for the fourth grade students in primary school towards their learning achievement. This instrument is in a form ofa website accessed with moodlebyzada.web.id. It consists of a main page and a special page. The main page is the first page that appears when accessing moodlebyzada.web.id, so it can be accessed by everyone.

The main page displays login menu, identity of the instrument developer, information on environmental damage prevention materials for fourth grade students in primary school, calendar as a reminder, and language options. The login menu would load the login page. Registered users can login using their own password and username, so they can also access its special pages. Information on environmental damage prevention materials are in forms of SK (Standard of Competence), $\mathrm{KD}$ (Basic Competence) and indicators of the materials. The reminder calendar displays the current schedule of a material or quiz. The language option in moodlebyzada.com provides Indonesian and English. Students canselect the language of instruction themselves. The special page displays special features and only registered users are able toaccess the page. There are three users who could enter the page, namely administrator, teachers and students. The administration isoperated by developer/administrator. The administrator has the access to add and subtract lessons and users, and manage the score. The teachers and administratorscan access to manage the scores. The students can access the materials including the questions that have been activated.

The instrument is a result of the development of Moodle 1.9. This development is focused on material delivery and evaluation. The material on the instrument is presented as a PPT (Power Point) file containing a summary of material on how to prevent environmental damage in both LMS and PPT formats. The power point format is provided to make learning process easier. The questions of evaluation or quiz contain questions of material on environmental damage prevention ina format of multiple choice questions. The quiz aims to test students' abilities. There are 20 items of evaluation in the form of multiple choice with the choices of answers $a, b$, $\mathrm{c}$, and $\mathrm{d}$.

Product validation is conducted by two experts. Questionnaires of instrument and material validation consist of 20 assessed items. The assessment is conducted once, and has been declared valid, but there are some suggestions and criticism from the validators (table 1). The validation result from the instrument expert is 4.9 which is a very valid criterion. 
Table 1. Results of Instrument and Material Validation

\begin{tabular}{llll}
\hline \multicolumn{2}{l}{ Instrument } & Validation & \multicolumn{2}{l}{ Material Validation } \\
\hline Aspect & Average & Aspect & Average \\
\hline $\begin{array}{l}\text { Display } \\
\text { aspect }\end{array}$ & 4,9 & $\begin{array}{l}\text { Material } \\
\text { content } \\
\text { Aspect }\end{array}$ \\
\hline $\begin{array}{l}\text { Aspectsof } \\
\text { material } \\
\text { content }\end{array}$ & 4,8 & $\begin{array}{l}\text { Aspect of } \\
\text { tests items }\end{array}$ \\
\hline $\begin{array}{l}\text { Aspectsof } \\
\text { use }\end{array}$ & 5 & Aspect of \\
\hline & language \\
\hline $\begin{array}{l}\text { Total } \\
\text { average }\end{array}$ & 4,9 & $\begin{array}{l}\text { Aspect of } \\
\text { utilization }\end{array}$ \\
\hline Criteria & Very valid & $\begin{array}{l}\text { Total } \\
\text { averages }\end{array}$ \\
\hline
\end{tabular}

The teacher's response to the instrument is obtained using teacher response questionnaire. The respondents are teachers of Natural Science subjects of experimental class and control class (tables 2). Teacher response questionnaire to instruments that have been developed with an average of 4.5 is an excellent criterion.

Table 2. Results of Teacher's Response Questionnaire

\begin{tabular}{|c|c|c|c|c|c|c|}
\hline $\begin{array}{l}\text { Aspe } \\
\text { ct }\end{array}$ & $\begin{array}{l}\text { Displ } \\
\text { ay } \\
\text { Aspec } \\
\text { t }\end{array}$ & $\begin{array}{l}\text { Aspect } \\
\text { of } \\
\text { materia } \\
1 \\
\text { content }\end{array}$ & $\begin{array}{l}\text { Aspect } \\
\text { of } \\
\text { utilizati } \\
\text { on }\end{array}$ & $\begin{array}{l}\text { Aspe } \\
\text { ct of } \\
\text { use }\end{array}$ & $\begin{array}{l}\text { Tota } \\
1 \\
\text { aver } \\
\text { age }\end{array}$ & $\begin{array}{l}\text { Criter } \\
\text { ia }\end{array}$ \\
\hline $\begin{array}{l}\text { Aver } \\
\text { a-ges }\end{array}$ & 4,7 & 4,5 & 4,5 & 4,3 & 4,5 & $\begin{array}{l}\text { Excel } \\
\text {-lent }\end{array}$ \\
\hline
\end{tabular}

The instruments that have been validated by experts and declared to be valid and worthy to use is then tested at school. The subjects are the students of class IV-A1 as the experimental class and the students of class IV-A3 as the control class in MI (Islamic Primary School) Istiqomah Sambas Purbalingga. The experimental class received the treatment or learning treatment using an online-based evaluation instrument using Moodle. The control class only performed regular learning activities or without any treatment. Both classes were given pre-test and post-test with the same type and number of questions. The average comparison of the pre-test and post-test results for the two classes after the research can be seen in the following table 3. The average score for post-test was higher than the average score for pre-test for each class.

Table 3. Results of Average Comparison of Pre-test and Post-test Result

\begin{tabular}{lccc}
\hline & $\begin{array}{c}\text { Type } \\
\text { No. }\end{array}$ & Test & \multicolumn{2}{c}{ Average } & \\
\cline { 3 - 4 } & & $\begin{array}{l}\text { Control } \\
\text { Class }\end{array}$ & $\begin{array}{l}\text { Experimental } \\
\text { Class }\end{array}$ \\
\hline 1. & Pretest & 66,6 & 77 \\
\hline 2. & Posttest & 75 & 82,5 \\
\hline
\end{tabular}

The average score of pre-test for the control class was 66.6 and the experimental class is 77 . The average score of post-test for the control class is 75 and the experimental class is 82.5 .
The trials were conducted in class IV-A1 at MI Istiqomah Sambas Purbalingga as the experimental class and class IV-A3 as the control class. Both classes were given pre-test and post-test with the same type and number of questions. The average that was obtained from both classes indicates that the experimental class has a higher post-test average score than the control class. The second post-test result of the class has already surpassed theminimum completeness criteria of Natural Science subjects which is 70.[7] The result of this research states that the use of Moodle affects student achievment. It aims to create an environment that allows for collaborative interaction among students as a standalone, or in addition to, conventional classroom instruction. [8]This paper presents an overview of E-learning environments that have implemented the Moodle platform. These environments include interactive activities combining simulations, short videos, virtual experiments, games and more, in order to enhance interactive learning based on constructivism theory, and allow students and teachers to learn skills for intelligent use of information and technological communication

The experimental class is the class used for testing an online-based evaluation instrument for Natural Science subject using Moodle. Based on these results, the posttest score for the experimental class is better because of the effect of an online-based evaluation instrument for Natural Science subject using Moodle. The control class is not treated; the post-test score obtained was lower. The improvement of experimental class learning achievement is in accordance with the research conducted by [9]on using Moodle in learning.

\section{CONCLUSION}

Based on the results of research and development, it can be summed up as follows:

1. The characteristics of instrument development results have been appropriated to the advice of material experts, media experts, teachers, and students.

2. Assessment of validator to online-based evaluation instrument for Natural Science subject conducted once by two experts. The average result of the questionnaire is 4.6 , so it can be concluded that the instrument is very valid.

3. The teacher assessment of the development of online-based instrument for Natural Science subject using Moodle is 4.5 with an excellent criterion.

4. Students' response to the development of onlinebased evaluation instrument for Natural Science subject using Moodle shows an average of 4.26 with excellent criteria.

5. Hypothesis test states the development of onlinebased evaluation instrument using Moodle has a good effect on student achievement in grade IV.

\section{REFERENCES}

[1] S.Arikunto, Dasar-Dasar Evaluasi Pendidikan, Jakarta: Bumi Aksara, 2012. 
[2] D.Darmawan, Pengembangan E-Learning : Teori dan Desain, Bandung: Remaja Rosdakarya, 2014.

[3] T. Aminoto dan H.Pathoni, "Penerapan Media ELearning Berbasis Schoology untuk Meningkatkan Aktivitas dan Hasil Belajar Materi Usaha dan Energi di Kelas XI SMA Negeri X Kota Jambi.," Sainmatika, vol. 8, no. 1, 2014.

[4] KI.Eka, "Pembelajaran Berbasis IT Menyongsong Era Digital," Seminar Nasional Pendidikan UPGRIS Semarang, p. 2, 4 Oktober 2017.

[5] H. Surjono, Membangun Course E-Learning Berbasis Moodle, Yogyakarta: UNY Press, 2013.
[6] S. Thiagarajan, S.Semmel dan M. Semmel, Instructional Development for Training Teachers of Exceptional Children : A Sourcebook, Bloomi ngtoon: Indiana University, 1974.

[7] S. Kotzer dan Y.Elran, "Learning and teaching with Moodle-based E-learning environments, combining learning skills and content in the fields of Math and Science \& Technology.," dalam 1st Moodle Research Conference, Creete, Greece, 2012.

[8] M. Hobbs dan Y. Hynson, "Development and Use of Moodle for online Student Suport," Studies in Self Access Learning, vol. 4, no. 3, pp. 196-207, 2013. 